\title{
Tri-iodothyronine regulates the production of interleukin- 6 and interleukin-8 in human bone marrow stromal and osteoblast-like cells
}

\author{
A Siddiqi ${ }^{1,2}$, J M Burrin ${ }^{1}$, D F Wood ${ }^{2}$ and J P Monson ${ }^{2}$ \\ ${ }^{1}$ Department of Clinical Biochemistry and ${ }^{2}$ Endocrinology, St Bartholomew's and Royal London School of Medicine and Dentistry, Whitechapel, \\ London E1 1BB, UK \\ (Requests for offprints should be addressed to A Siddiqi, Department of Endocrinology, Alexandra Wing, St Bartholomew's and Royal London School of \\ Medicine, Whitechapel, London E1 1BB, UK)
}

\begin{abstract}
Hyperthyroidism is associated with increased bone resorption but the mechanisms by which thyroid hormone (T3) affects bone cell metabolism remain unclear. Recently it has been suggested that T3 stimulates osteoclastic resorption indirectly through the release of soluble mediators from osteoblasts. The aim of the present study was to investigate whether the T3-induced increase in bone resorption could be due to the regulation of cytokine production by human osteoblasts $(\mathrm{hOb})$.

The effects of $\mathrm{T} 3(1,10,100 \mathrm{nM})$ and $\mathrm{IL}-1 \beta$ $(100 \mathrm{U} / \mathrm{ml})$ as the positive control were examined on cytokine protein release and mRNA levels in cultured hOb cell lines (MG63, SaOs-2), primary hOb and human bone marrow stromal (hBMS) cells. T3 increased IL-6 and IL-8 mRNA levels as well as IL-6 and IL-8 protein release into the culture media from MG63 and hBMS cells in a
\end{abstract}

time- and dose-dependent manner. The maximal effect on protein release in hBMS cells occurred at $24 \mathrm{~h}$ with a dose of T3 $10 \mathrm{nM}$ (IL-6 5.5 $\pm 1 \cdot 1$-fold above controls; IL-8 $3 \cdot 7 \pm 0 \cdot 5$-fold above controls, $P<0 \cdot 05)$. At the same time, mRNA levels in hBMS cells were increased $6 \cdot 2 \pm$ $0 \cdot 8$-fold for IL-6 $(P<0 \cdot 05)$ and $5 \cdot 7 \pm 0 \cdot 8$-fold for IL-8 $(P<0 \cdot 05)$. Similar results were obtained in MG63 cells but no response was seen in SaOs-2 or hOb cells despite measurable basal production. Nor was there detectable regulation of IL-1 $\beta$, IL-3, IL-11, IL-4 or granulocyte macrophage-colony stimulating factor by $\mathrm{T} 3$ in any cell type.

In conclusion, T3 increases IL- 6 and IL-8 production by MG63 and hBMS cells, suggesting that IL-6 and IL-8 may be T3-regulated genes in osteoblasts.

Journal of Endocrinology (1998) 157, 453-461

\section{Introduction}

Hyperthyroidism is characterised by an increase in bone turnover accompanied by a negative calcium balance and reduction in bone mineral density (Mosekilde \& Melsen 1978). Both histological and biochemical evidence suggests that this is due to stimulation of osteoclastic resorption (Garnero et al. 1994, Siddiqi et al. 1997). In vitro studies with organ cultures of neonatal mouse calvariae and fetal rat limb have also shown direct stimulation of bone resorption by tri-iodothyronine (T3) (Mundy et al. 1976, Klaushofer et al. 1989). The mechanism for this effect of $\mathrm{T} 3$ on bone is not fully understood and in particular T3-responsive genes in bone cells have yet to be identified. Recent reports (Allain et al. 1992, Britto et al. 1994) have suggested that the effects of $\mathrm{T} 3$ on osteoclastic bone resorption are indirect and mediated by osteoblasts. T3 receptors (TR) have been demonstrated in rat, mouse and human osteoblast (hOb) cell lines (Sato et al. 1987, Kasono et al. 1988, Allain et al. 1996) and it is thought that activation of these osteoblastic TRs results in the release of soluble agents which stimulate osteoclastic bone resorption (Klaushofer et al. 1989, Lakatos \& Stern 1992, Tarjan \& Stern 1995). Since the bone resorbing activity of T3 in vitro can be inhibited by cyclosporin A (Lakatos \& Stern 1992) and by interferon- $\gamma$ (Klaushofer et al. 1989), cytokines are likely mediators of $\mathrm{T} 3$ action.

Several cytokines with osteotrophic effects, such as interleukin-6 (IL-6), IL-8, IL-3, IL-1 $\beta$ and granulocyte macrophage-colony stimulating factor (GM-CSF), are now known to be released by human osteosarcoma cell lines, hOb and human bone marrow stromal (hBMS) cells (osteoblast progenitor cells) (Chaudhary \& Avioli 1994, Passeri et al. 1994, Manolagas \& Jilka 1995). IL-6 in particular is a potent regulator of osteoclast differentiation and elicits bone resorption both in vivo and in in vitro models that contain early osteoclast precursors (Ishimi et al. 1990, Black et al. 1991). More recently, a role for IL-8 in bone metabolism has been shown by the demonstration of expression of IL-8 receptors on osteoclasts (Collin-Osdoby 
et al. 1996) and its regulatory effects on osteoclast development and activity (Fuller et al. 1995).

The present study was designed to investigate the potential role of cytokines as mediators of $\mathrm{T} 3$ action on bone cells. To address this hypothesis we have examined the effects of $\mathrm{T} 3$ on medium cytokine concentrations and cytokine gene expression in cultured hOb-like cell lines, primary cultures of hOb and hBMS cells.

\section{Materials and Methods}

\section{Cell culture}

The hOb-like cell lines MG63 and SaOs-2 were maintained in $\alpha$-minimum essential medium (Gibco BRL, Life Technologies Ltd, Paisley, Strathclyde, UK) containing 10\% FCS (Gibco BRL), penicillin, streptomycin and fungizone (hereafter referred to as medium) at $37^{\circ} \mathrm{C}$ in a humidified atmosphere containing $5 \% \mathrm{CO}_{2}$ in air. Cells were sub-cultured twice a week.

hBMS cells were prepared from bone marrow aspirates obtained from patients in remission from haematological malignancies and ethical approval was obtained from the East London and City Health Authority Ethics Committee. A modification of the method described by Haynesworth et al. (1992) was used. Briefly, marrow cells were pelleted by centrifugation at $500 \mathrm{~g}$ for $10 \mathrm{~min}$, resuspended in medium and plated at a density of $2 \times 10^{6}$ cells $/ 75 \mathrm{~cm}^{2}$ tissue culture flask. Cells were allowed to attach without disturbance for 7 days. After the attachment period, half the culture medium was replaced with fresh medium and subsequently media changed at 2- to 3-day intervals. At confluence, cells were trypsinised, counted and plated into multi-well culture plates. First passage cells were used in all experiments. Although hBMS cell cultures appear homogenous, they represent not clonal cell lines but multi-colony derived cells. Therefore the cultures exhibit heterogeneity between samples due to potentially differing proportions of one cell type to another (preosteogenic vs preadipogenic vs prechondrogenic). To exclude significant proportions of non-osteoblastic cells, we extensively characterised the phenotype of our cells (see below).

$\mathrm{hOb}$ were cultured from bone explants by the method of Robey \& Termine (1985) using trabecular bone discarded during orthopaedic surgery from men and women aged between 50 and 85 years. Connective tissue was dissected from bone fragments, which were then washed in PBS, diced into $2-4 \mathrm{~mm}$ pieces and placed in tissue culture flasks in medium. Cells growing out from the bone chips were passaged once and grown to confluence. All assays were done on cells trypsinised and subcultured at the end of the first passage.

\section{Characterisation of phenotype}

The osteoblastic phenotype of confluent cells from all four sources was confirmed by measuring alkaline phosphatase
(ALP) positivity and $1,25(\mathrm{OH})_{2} \mathrm{D}_{3}$ induction of osteocalcin. ALP staining was confirmed using the ALP substrate 5-bromo 4-chloro 3-indolyl phosphate which gives a blue oxidation product following the addition of nitroblue tetrazolium chloride (Sigma Chemicals, Poole, Dorset, UK). Intense staining was seen with hBMS and $\mathrm{SaOs}-2$ cells, moderate staining with $\mathrm{hOb}$ and low intensity staining seen with MG63 cells. Osteocalcin production was determined using the OSTK-PR (CIS Biointernational, Gif-sur-Yvette, Cedex, France) radioimmunoassay. hBMS, SaOs-2 and MG63 cells had only $1,25(\mathrm{OH})_{2} \mathrm{D}_{3}$-dependent osteocalcin secretion, in contrast to hOb cells which had detectable basal osteocalcin secretion. For chondrocyte and adipocyte analyses, cells were washed three times in PBS, followed by fixation with $10 \%$ buffered formalin for $5 \mathrm{~min}$. The cultures were then washed with water and stained for $30 \mathrm{~min}$ with Alcian blue $(10 \%$ in $0.1 \mathrm{M} \mathrm{HCl})$ for chondrocytes or overnight with oil red $\mathrm{O}(0.5 \%$ in propylene glycol) for adipocytes. No staining was observed in any of the cell types.

\section{Cytokine and growth factor response experiments}

Cells were plated into multi-well plates at a density of 10000 cells $/ \mathrm{cm}^{2}$ in medium. Following overnight incubation, cells were washed in PBS and placed in fresh medium containing charcoal-stripped serum. Twenty four hours later, cells were treated with either $1 \mathrm{nM}, 10 \mathrm{nM}$ or 100 nM T3 (Sigma Chemicals), concentrations which correspond to physiological, pathological and pharmacological levels in vivo. Control wells were incubated with either no additions (negative control, C) or with $100 \mathrm{U} / \mathrm{ml}$ human recombinant IL-1 $\beta$ (RD Systems Europe Ltd, Abingdon, Oxon, UK) as positive control. Media were analysed for IL-6, IL-1 $\beta$, IL-4, GM-CSF, IL-3 and TNF- $\alpha$ at 6 and $24 \mathrm{~h}$ and for IL-8 at 3, 6, 8, 24 and $48 \mathrm{~h}$ by competitive ELISA assays (Eurogenetics UK Ltd, Middlesex, UK) using human recombinant cytokine or growth factors as standard. The lower limit of detection varied with the cytokine assayed and was $0.2 \mathrm{ng} / \mathrm{l}$ for IL-1 $\beta, 1 \mathrm{ng} / 1$ for IL-6, IL-8, IL-4 and TNF- $\alpha, 7 \mathrm{ng} / 1$ for GM-CSF and IL-11 and $31 \mathrm{ng} / 1$ for IL-3. The betweenbatch coefficient of variation of these assays was $<13 \%$. Individual experiments were done in duplicate and each experiment was repeated at least three times. Cell extracts were used for mRNA isolation as described below.

\section{$m R N A$ isolation, $c D N A$ synthesis and PCR analysis}

mRNA was isolated using the QuickPrep micro mRNA purification kit (Pharmacia Biotech, St Albans, Herts, UK). Briefly, cells were extracted with guanidinium thiocyanate and the extract was incubated with oligo(dT)cellulose to allow binding with the poly(A) RNA. After washing in low- and high-salt buffer $(10 \mathrm{mM}$ Tris- $\mathrm{HCl}$ ( $\mathrm{pH} 7 \cdot 5), 1 \mathrm{mM}$ EDTA and $\mathrm{NaCl}(0.1 \mathrm{M}$ or $0.5 \mathrm{M}$ 
respectively)), the mRNA was eluted with $10 \mathrm{mM}$ Tris- $\mathrm{HCl}$ and $1 \mathrm{mM}$ EDTA and precipitated with glycogen and potassium acetate. The concentration of mRNA was determined by measuring the absorbance at $260 \mathrm{~nm}$. Approximately 1-2 $\mu \mathrm{g}$ mRNA was recovered from each purification and stored at $-70{ }^{\circ} \mathrm{C}$ until use.

A total of $0.2 \mu \mathrm{g}$ mRNA was sufficient for oligo(deoxythymidine) ${ }_{18}$-primed cDNA synthesis using the First Strand cDNA Synthesis kit (Pharmacia Biotech). Following heat denaturation at $65{ }^{\circ} \mathrm{C}$ for $10 \mathrm{~min}$, the mRNA was incubated at $37^{\circ} \mathrm{C}$ for $1 \mathrm{~h}$ in a total reaction volume of $33 \mu \mathrm{l}$ containing $10 \mathrm{mM}$ Moloney murine leukaemia virus-reverse transcriptase (MMLV-RT), deoxy-NTP, $200 \mathrm{mM}$ DTT and $0 \cdot 2 \mu \mathrm{g} / \mu \mathrm{l} \operatorname{not} 1-\mathrm{d}(\mathrm{T})_{18}$ bifunctional primer. Reverse transcription was also performed in the absence of MMLV-RT. PCR carried out on this RT product yielded no PCR product, confirming no genomic DNA contamination. All cDNA was stored at $-70{ }^{\circ} \mathrm{C}$ until use.

Five microlitres cDNA were used for PCR amplification thus allowing six amplifications to be performed from each sample. For the purposes of semiquantitation and to reduce the variability between samples, PCR components were premixed before addition to individual PCR tubes. The $50 \mu \mathrm{l}$ reaction mixture contained $0.2 \mathrm{mM}$ dNTP, $5 \mu \mathrm{l}$ 10-fold concentrated PCR buffer, $5 \mu \mathrm{l}$ cDNA and $100 \mathrm{pM}$ glyceraldehyde-3-phosphate dehydrogenase (GAPDH) primers and either IL-6 or IL-8 primers. The sequences of the primers were specific as confirmed by computer assisted search of GenBank. IL-6 primers (forward primer 5' CTG/CTC/CTG/GTG/ TTG/CCT, reverse primer 5' CCT/GCA/GCC/ACT/ GGT/TCT) were used to amplify a $511 \mathrm{bp}$ DNA fragment and were designed to span introns in order to avoid false positives from genomic DNA. The IL-8 primers amplifying a DNA fragment of $302 \mathrm{bp}$ were as described by Birch et al. (1993). GAPDH, a cell-cycle, stimulation-independent house-keeping gene, was used to normalise mRNA levels. Amplification of human GAPDH mRNA from the cDNA was achieved by using primers from ClonTech (Cambridge, UK) in each PCR and generated a $986 \mathrm{bp}$ fragment. The PCR mixture was heated to $90{ }^{\circ} \mathrm{C}$ for $3 \mathrm{~min}$ and cooled to $84{ }^{\circ} \mathrm{C}$ before addition of $2.5 \mathrm{U}$ Taq (Boehringer Mannheim, Lewes, East Sussex, UK) followed by 30 cycles of denaturation at $94{ }^{\circ} \mathrm{C}$ for $30 \mathrm{~s}$, annealing at $55^{\circ} \mathrm{C}$ for $30 \mathrm{~s}$ and extension at $72{ }^{\circ} \mathrm{C}$ for $45 \mathrm{~s}$. Controls with water replacing template were included in all experiments. PCR products were separated by electrophoresis using $1.6 \%$ agarose gels stained with ethidium bromide. HincII-digested DNA was run in parallel as a molecular weight marker.

\section{Method of quantification}

All RT reactions used oligo(deoxythymidine) ${ }_{18}$-primed RNA to minimise the variations in RT efficiency seen when using specific RT primers. Following optimisation of PCR conditions for each primer pair, comparative kinetic analyses (Noonan et al. 1990, Salomon et al. 1992) were performed to determine the phase during which there was exponential increase in PCR product before a plateau was reached. It was at this point that the PCR was terminated, allowing semiquantitative data to be obtained.

The gels were photographed on a UV light box with Polaroid type 665 film to yield a negative. Using wholeband analysis software (BioImage Computer Systems, Crewe, Chester, UK), each negative was scanned, the image digitised and the optical density of each PCR generated band measured. This optical density was in turn a measure of the quantity of PCR product (Nakayama et al. 1992). The value for each band was expressed as a ratio to the quantity of GAPDH. The coefficients of variation for repeated measurements were less than $20 \%$. The specificity of the amplified bands was validated by sequencing of the PCR product using Taq cycling with fluorescent labelled dye terminators.

\section{Statistical analysis}

Results are expressed as means \pm S.E.M. for each experimental group and were compared by one-way ANOVA. When the $F$ statistic was significant $(P<0 \cdot 05)$, the analysis was continued using Fisher's multiple comparisons test.

\section{Results}

\section{Cytokine response studies}

Both of the hOb-like cell lines (MG63 and SaOs-2), the hOb and the hBMS cells released IL-6 and IL- 8 basally. However, the constitutive expression and the response to T3 varied with the cell type. Higher basal release of IL-6 and IL-8 was present in hOb (IL-6: $6 \mathrm{~h}$ $1063 \pm 111 \cdot 2 \mathrm{ng} / 1, \quad 24 \mathrm{~h} \quad 4463 \pm 540 \mathrm{ng} / \mathrm{l} ; \quad$ IL-8: $6 \mathrm{~h}$ $752 \pm 98 \cdot 3 \mathrm{ng} / \mathrm{l}, 24 \mathrm{~h} 2326 \pm 221 \mathrm{ng} / \mathrm{l})$ and hBMS cells (IL-6: 6 h $24900 \pm 6300 \mathrm{ng} / 1,24$ h $75100 \pm 203$ ng/l; IL-8: 6 h $48100 \pm 9300 \mathrm{ng} / 1,24 \mathrm{~h} 107200 \pm 50100 \mathrm{ng} / \mathrm{l}$ ) compared with the osteosarcoma cell lines MG63 (IL-6: 6 h $204 \cdot 8 \pm 41 \cdot 4 \mathrm{ng} / 1,24 \mathrm{~h} 211 \cdot 8 \pm 59 \cdot 6 \mathrm{ng} / \mathrm{l}$; IL-8: 6 h $21 \cdot 0 \pm 6 \cdot 7 \mathrm{ng} / 1,24 \mathrm{~h} 38 \cdot 86 \pm 9 \cdot 1 \mathrm{ng} / \mathrm{l}$ ) and SaOs-2 (IL-6 and IL-8<1-3 ng/l).

The levels in $\mathrm{hOb}$ and $\mathrm{SaOs}-2$ did not rise further following $24 \mathrm{~h}$ incubation with T3, although both cells did respond to the positive control IL-1 $\beta$ by $24 \mathrm{~h}(\mathrm{hOb}$ : IL-6 $8809 \pm 203$ ng/l, $P<0 \cdot 05 ; \quad$ IL-8 $4032 \pm 193$ ng/l, $P<0 \cdot 05 ;$ SaOs-2: IL-6 21.13 $\pm 5 \cdot 6 \mathrm{ng} / \mathrm{l}$; IL-8 15.02 $5 \cdot 3 \mathrm{ng} / \mathrm{l})$. In contrast MG63 and hBMS cells responded in a dose- (Fig. 1) and time-dependent (Fig. 2) manner to both T3 and IL-1 $\beta$, with an increase in the release of IL-6 and IL-8. The maximum response of 5.5-fold above control wells was reached at $24 \mathrm{~h}$ with pathological levels 


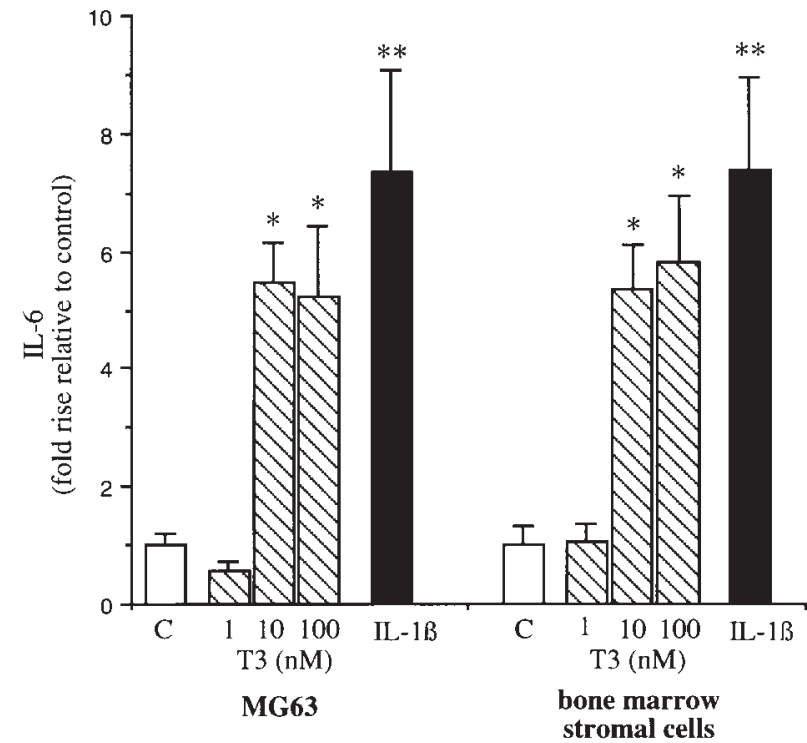

Figure 1 Dose effect of T3 on IL-6 production from MG63 and hBMS cells. Cells were cultured in charcoal-stripped medium for $24 \mathrm{~h}$ prior to treatment with either no stimulant (C), T3 1, 10 or $100 \mathrm{nM}$ or IL-1 $\beta 100 \mathrm{U} / \mathrm{l}$. Media was assayed $24 \mathrm{~h}$ later for IL- 6 by ELISA and results are expressed as the fold increase above IL-6 production in unstimulated wells for both MG63 $(211 \cdot 8 \pm$ $59 \cdot 6 \mathrm{ng} / \mathrm{l})$ and hBMS cells $(75100 \pm 203 \mathrm{ng} / \mathrm{l})$ Each bar represents the mean \pm S.E.M. for three experiments done in duplicate. ${ }^{*} P<0 \cdot 05,{ }^{* *} P<0 \cdot 01$ vs $C$.

of T3 $(10 \mathrm{nM})$ and increasing the $\mathrm{T} 3$ concentration had no further effect. Similarly, IL-8 was produced both constitutively and on stimulation with T3 in MG63 and hBMS cells (Figs 3 and 4 ) when a maximum 3.8- and 3.7-fold rise was seen in MG63 and hBMS cells respectively at $24 \mathrm{~h}$. Interestingly, MG63 showed a significant response with T3 $1 \mathrm{nM}$, but hBMS cells were stimulated only at T3 $10 \mathrm{nM}$, at which concentration, IL-6 and IL-8 levels approached that of the positive control IL-1 $\beta$ (Figs 1 and 3).

The release of IL- $1 \beta$, TNF- $\alpha$, IL-4, IL-3 and GM-CSF was not detected either basally or on stimulation with T3 in any cell type studied. IL-11 was detectable basally in $\mathrm{hOb}(50 \cdot 0 \pm 11 \cdot 2 \mathrm{ng} / \mathrm{l})$ and hBMS cells $(331 \pm 23 \cdot 6 \mathrm{ng} / \mathrm{l})$ but was unresponsive to $\mathrm{T} 3$ stimulation at any of the concentrations used.

\section{Effects of T3 on IL-6 and IL-8 mRNA expression in MG63 and hBMS cells}

To study whether cytokine protein release was related to mRNA expression in the cells, RT-PCR was performed on the cDNA extracted from cells treated with or without T3 and IL-1 $\beta$. Cytokine mRNA expression was not investigated in $\mathrm{hOb}$ or $\mathrm{SaOs}-2$ as cytokine release from these cells had been unaffected by T3 stimulation. To provide a semiquantitative assessment of mRNA expres-

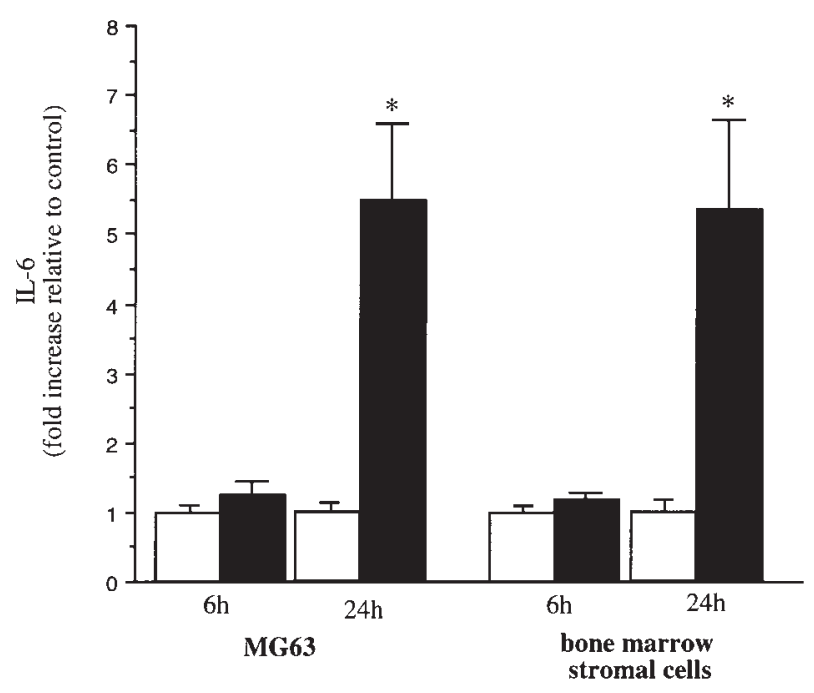

Figure 2 Time course effect of T3 on production of IL-6. MG63 and hBMS cells were cultured for $24 \mathrm{~h}$ in charcoal-stripped medium prior to stimulation with either no treatment (open bar) or T3 $10 \mathrm{nM}$ (solid bar). Media was assayed by ELISA for IL-6 at $6 \mathrm{~h}$ and $24 \mathrm{~h}$ and results are expressed as the fold increase above IL-6 production in unstimulated wells for both MG63 $(6 \mathrm{~h}$ $204 \cdot 8 \pm 41 \cdot 4 \mathrm{ng} / \mathrm{l}, 24 \mathrm{~h} 211 \cdot 8 \pm 59 \cdot 6 \mathrm{ng} / \mathrm{l})$ and hBMS cells (6 h $24900 \pm 6300$ ng/l, 24 h $75100 \pm 203$ ng/l). Each bar represents the mean \pm S.E.M. for three experiments done in duplicate. ${ }^{*} P<0 \cdot 05$ compared with untreated wells.

sion, standardised PCR protocols were established as described in the Methods section. Figures 5 and 6 indicate the results of ratios of expression of IL-6 and IL-8 respectively to GAPDH mRNA in MG63 and hBMS cells. These ratios are expressed as fold increases relative to control samples.

Although IL-6 and IL-8 mRNA were detectable at $6 \mathrm{~h}$, no response was seen to T3 in either MG63 or hBMS cells (data not shown). In MG63 cells after $24 \mathrm{~h}$, there was a dose-dependent rise in IL-6 (1.6 $\pm 0 \cdot 5$-fold rise, n.s., T3 $1 \mathrm{nM})$ which reached significance with T3 $10 \mathrm{nM}$ $(4 \cdot 8 \pm 0 \cdot 8$-fold rise, $P<0 \cdot 05)$. A similar dose-dependent rise in IL-6 mRNA expression was observed in hBMS cells with T3 $1 \mathrm{nM}$ and T3 $10 \mathrm{nM}(1 \cdot 9 \pm 0 \cdot 5$-fold rise (n.s.) and $6 \cdot 2 \pm 0 \cdot 8$-fold rise $(P<0 \cdot 05)$ respectively. GAPDH transcripts were unchanged by any treatment.

A similar induction in IL-8 mRNA expression was seen in MG63 and hBMS cells. At $24 \mathrm{~h}$ in MG63 cells there was a significant $4 \cdot 3 \pm 0 \cdot 6$-fold rise $(P<0 \cdot 05)$ in IL-8 mRNA with T3 $1 \mathrm{nM}$ which increased to $5 \cdot 4 \pm$ $0 \cdot 9$-fold $(P<0 \cdot 05)$ with T3 at $10 \mathrm{nM}$. Similar responses were seen in hBMS cells with a $2 \cdot 8 \pm 0 \cdot 5-$ (n.s.) and $5 \cdot 7 \pm 0 \cdot 8$-fold rise $(P<0 \cdot 05)$ with T3 $1 \mathrm{nM}$ and $10 \mathrm{nM}$ respectively.

In both MG63 and hBMS cells, IL-1 $\beta$ (100 U/l) was used as a positive control for induction of IL-6 and IL-8 mRNA expression and at $24 \mathrm{~h}$ caused a $8.2 \pm$ $1 \cdot 2$ - and $7 \cdot 3 \pm 1 \cdot 1$-fold rise $(P<0 \cdot 01)$ respectively in 


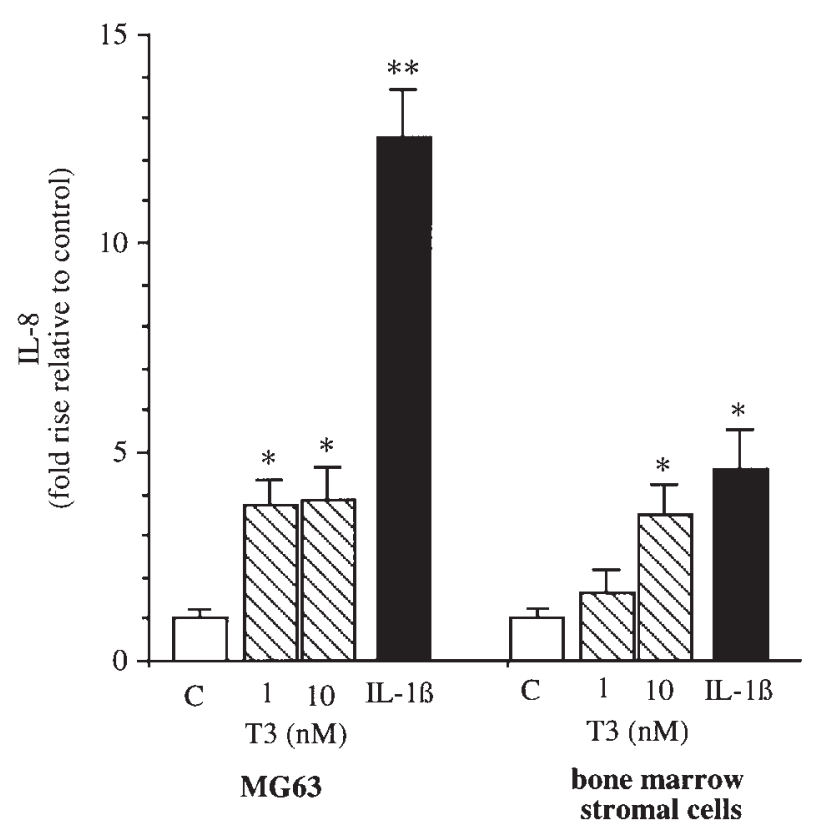

Figure 3 Dose effect of T3 on IL-8 production from MG63 and hBMS cells. Cells were cultured in charcoal-stripped medium for $24 \mathrm{~h}$ prior to treatment with either no stimulant (C), T3 1 or 10 $\mathrm{nM}$ or IL-1 $\beta 100 \mathrm{U} / \mathrm{l}$. Media was assayed $24 \mathrm{~h}$ later for IL-8 by ELISA and results are expressed as the fold increase above IL-8 production in unstimulated wells for both MG63 $(38 \cdot 86 \pm 9 \cdot 1 \mathrm{ng} / \mathrm{l})$ and hBMS cells $(107200 \pm 50100 \mathrm{ng} / \mathrm{l})$. Each bar represents the mean \pm S.E.M. for three experiments done in duplicate. ${ }^{*} P<0 \cdot 05$, ${ }^{*} P<00 \cdot 01$ vs $C$.

IL-6 mRNA and a $7 \cdot 8 \pm 1 \cdot 2$ - and $7 \cdot 4 \pm 1 \cdot 1$-fold rise $(P<0 \cdot 01)$ in IL-8 mRNA respectively.

\section{Discussion}

The results of the present study demonstrate that $\mathrm{T} 3$ increases IL-6 and IL-8 production from both hBMS cells and the human osteosarcoma cell line MG63 cell in a dose- and time-dependent fashion. This stimulated production of IL- 6 and IL- 8 occurred in the absence of effects on $\mathrm{T} 3$ on IL-1 $\beta$ release, suggesting that, in these human cells, T3 is not potentiating the stimulatory effects of IL-1 $\beta$ as previously proposed in studies using fetal rat limb bone cultures (Tarjan \& Stern 1995). Our in vitro evidence suggests that T3 interacts directly with osteoblasts, stimulating them to produce IL-6 and IL-8, thus providing a mechanistic paradigm whereby T3 could modulate bone resorption. Consistent with this hypothesis are recently reported studies in vivo documenting high levels of serum IL-6 and soluble IL-6 receptor in patients with hyperthyroidism (Salvi et al. 1996, Lakatos et al. 1997).

hBMS cells have been previously reported to produce IL-6 and IL-8 in response to stimulation with a number of factors including parathyroid hormone (PTH) (Kim

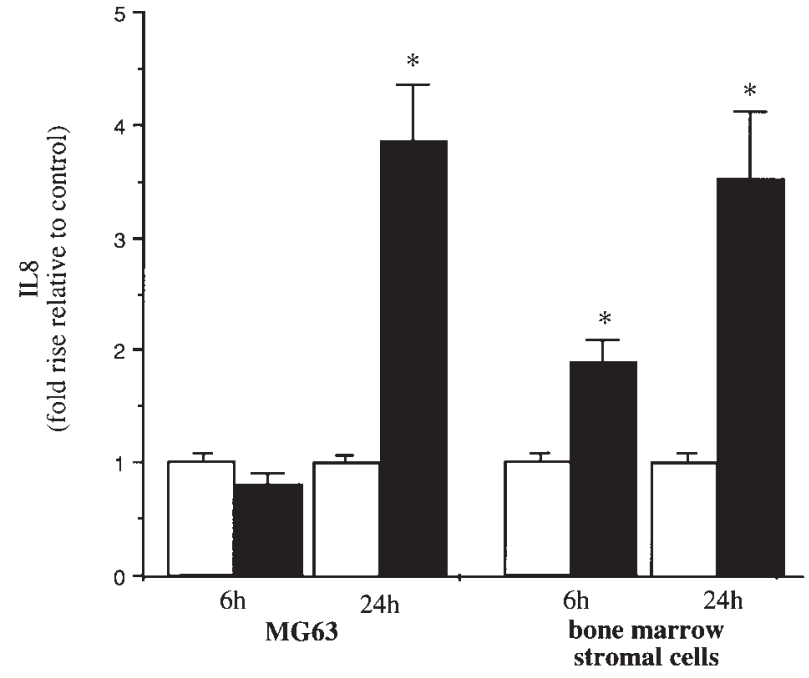

Figure 4 Time course effect of T3 on production of IL-8. MG63 and hBMS cells were cultured for $24 \mathrm{~h}$ in charcoal-stripped medium prior to stimulation with either no treatment (open bar) or T3 $10 \mathrm{nM}$ (solid bar). Media was assayed by ELISA for IL-8 at 6 and $24 \mathrm{~h}$ and results are expressed as the fold increase above IL-8 production in unstimulated wells for both MG63 $(6 \mathrm{~h}$ $21 \cdot 0 \pm 6 \cdot 7 \mathrm{ng} / \mathrm{l}, 24 \mathrm{~h} 38 \cdot 86 \pm 9 \cdot 1 \mathrm{ng} / \mathrm{l})$ and hBMS cells $(6 \mathrm{~h}$ $48100 \pm 9300 \mathrm{ng} / \mathrm{l}, 24 \mathrm{~h} 107200 \pm 50100 \mathrm{ng} / \mathrm{l})$. Each bar represents the mean \pm S.E.M. for three experiments done in duplicate. ${ }^{*} P<0.05$ compared with untreated wells.

et al. 1997), IL-1 and tumour necrosis factor (TNF)- $\alpha$ (Chaudhary \& Avioli 1994). Both PTH and IL-1 were shown to cause an approximately 2-fold increase in IL-6 levels (Kim et al. 1997) after $24 \mathrm{~h}$ of incubation. In our studies, IL-1 $\beta$ (at an equivalent dose of $100 \mathrm{U} / \mathrm{ml}$ ) produced a 5-5-fold increase in IL-6, an increase that was matched by $\mathrm{T} 3$ at a concentration of $10 \mathrm{nM}$. Interestingly, stimulated levels of IL-6 produced in response to T3 in both types of cells were in the range $(1-10 \mathrm{ng} / \mathrm{ml})$ shown previously to promote bone resorption (Roodman 1992).

hBMS cells are reported as having low basal levels of IL-8 which can be dramatically increased by both IL- $1 \beta$ and TNF- $\alpha$ (Chaudhary \& Avioli 1994). We found similar low basal levels of IL-8 in MG63 cells but higher levels in hBMS cells.

Basal mRNA expression of IL-6 and IL- 8 mRNA has been demonstrated in hOb and hBMS cells and regulation of gene expression in response to glucocorticoids, IL-1 and growth hormone (GH) (Littlewood et al. 1991a, Chaudhary \& Avioli 1996, Swolin \& Ohlsson 1996) has been documented. We have now shown T3-dependent upregulation of IL-6 and IL-8 mRNA expression in MG63 and hBMS. These additional data would suggest that the increased output of IL- 6 and IL- 8 may occur as a result of effects of T3 on IL-6 and IL-8 gene expression. mRNA levels at $24 \mathrm{~h}$ were higher than at $6 \mathrm{~h}$, which correlates well with the peak release of IL-6 and IL-8 into the culture media. This induction of mRNA could be due 

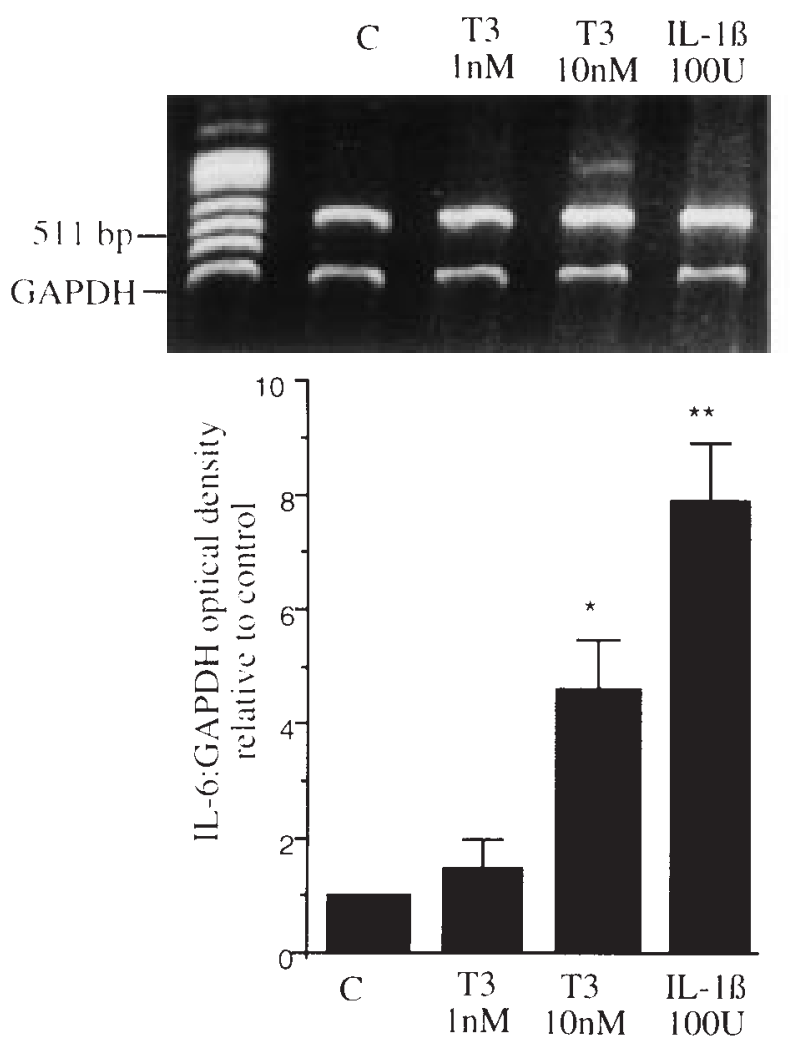

MG63
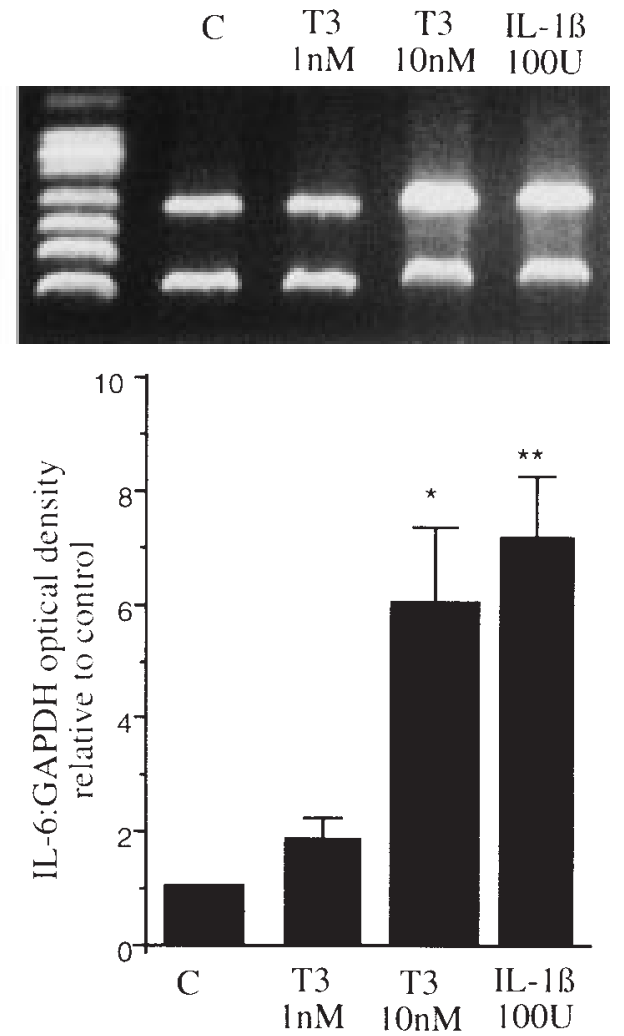

bone marrow stromal cells

Figure 5 RT-PCR was performed on mRNA isolated from MG63 and hBMS cells demonstrating the presence of mRNAs encoding IL- 6 and GAPDH in cells treated for $24 \mathrm{~h}$ with either no stimulant (C), $1 \mathrm{nM} \mathrm{T3,} 10 \mathrm{nM}$ T3 or IL-1 $\beta$ $100 \mathrm{U}$. Products were run on $1 \cdot 6 \%$ agarose gel and stained with ethidium bromide. The corresponding histograms show the ratio of the densitometric values of IL- 6 to GAPDH transcripts relative to the unstimulated control, C. Each bar represents the mean \pm S.E.M. for three experiments. ${ }^{\star} P<0 \cdot 05,{ }^{*} P<0 \cdot 01$ relative to $C$.

to either an upregulation of gene transcription or to mRNA stabilisation. The latter mechanism is a particular feature of cytokine genes as many contain a reiterated AU motif in the $3^{\prime}$ untranslated region which mediates rapid mRNA decay (Wilson \& Treisman 1988). In addition to a possible post-transcriptional effect, the absence of an early mRNA response leads us to speculate that this effect of T3 on IL-6 and IL- 8 maybe indirect and indeed there is no immediately recognisable $\mathrm{T} 3$ response element in the IL- 6 or IL- 8 promoter. Both these possibilities need to be pursued in future studies.

Basal levels of IL-6 and IL-8 in hOb were comparable with previously reported levels of 120-2000 pg/ml which are seen in trabecular bone explants (Chaudhary et al. 1992) but, as demonstrated for PTH and $1,25(\mathrm{OH})_{2} \mathrm{D}_{3}$ (Littlewood et al. 1991a), did not rise further with T3. Moreover, IL-6 does not stimulate bone resorption in these cells (Littlewood et al. 1991b) arguing against a role for these cells in osteotrophic hormone-induced bone resorption. SaOs-2 cells did not respond either to $\mathrm{T} 3$ stimulation. This difference in responsiveness between the cell types studied is intriguing and the explanation may lie in the expression of TRs in osteoblasts with MG63 and hBMS cells having higher levels of expression. Allain et al. (1996) have recently demonstrated the presence of TR $\beta$ and TR $\alpha 2$ in MG63 cells but similar data on TR expression in hBMS cells is currently not available.

An alternative explanation may be related to the phenotypic characteristics of the four cell types studied. It is now increasingly accepted that, when compared with hOb, hBMS cells represent an earlier stage in the osteoblast life cycle (Rickard et al. 1996) and that they act as the source of the osteoprogenitor cells from which the renewal of the osteoblast population at the bone surface is considered to occur via differentiation along the osteoblast lineage (Wlodarski 1990). The differences between MG63 and SaOs-2 cells are less clear. MG63 cells are thought to exhibit an earlier osteoblast phenotype based primarily on 


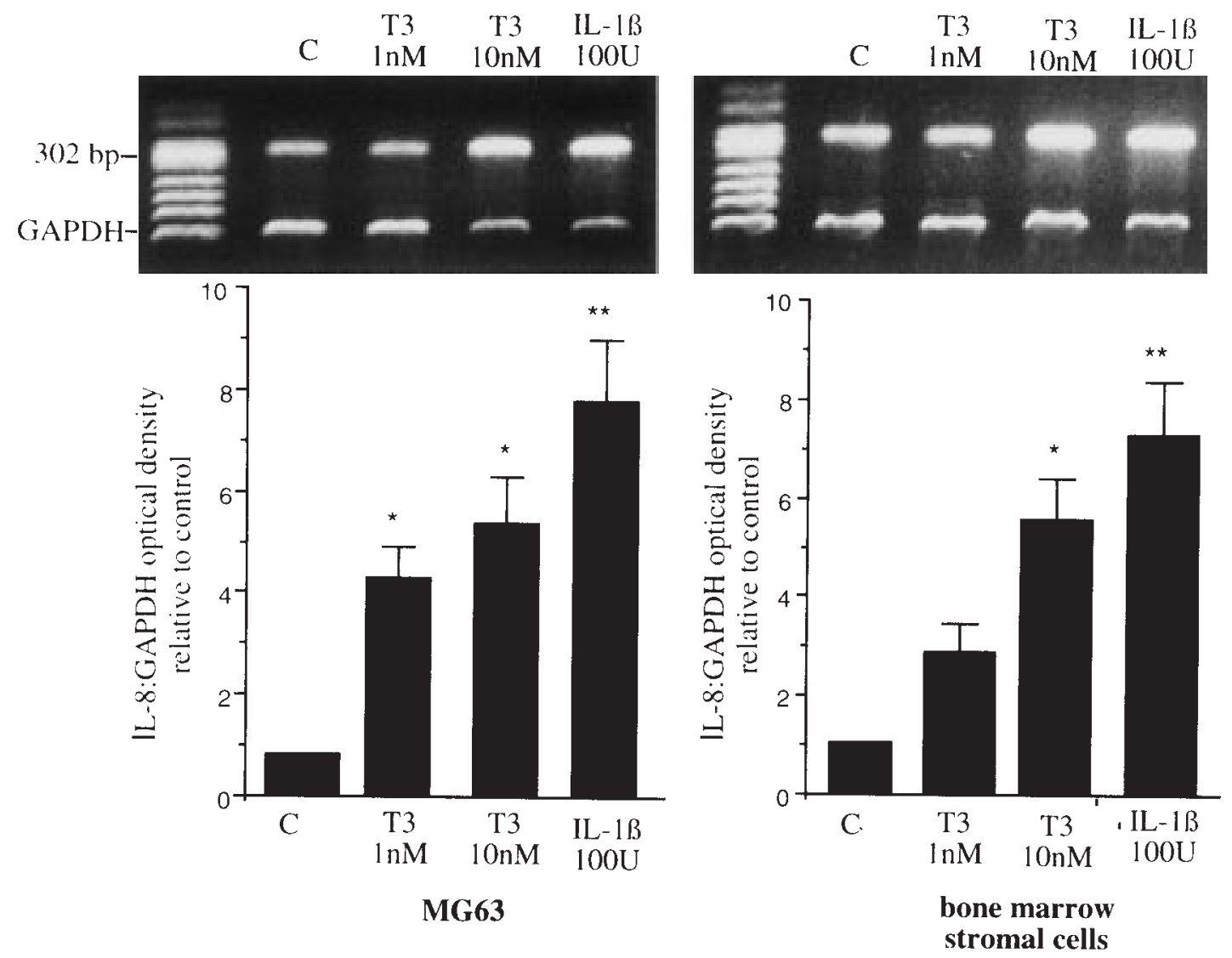

Figure 6 RT-PCR was performed on mRNA isolated from MG63 and hBMS cells demonstrating the presence of mRNAs encoding IL-8 and GAPDH in cells treated for $24 \mathrm{~h}$ with either no stimulant (C), $1 \mathrm{nM} \mathrm{T3,} 10 \mathrm{nM} \mathrm{T3}$ or IL-1 $100 \mathrm{U}$. Products were run on $1.6 \%$ agarose gel and stained with ethidium bromide. The corresponding histograms show the ratio of the densitometric values of IL-8 to GAPDH transcripts relative to the unstimulated control, C. Each bar represents the mean \pm S.E.M. for three experiments. ${ }^{*} P<0 \cdot 05,{ }^{*} * P<0 \cdot 01$ relative to $C$.

ALP expression, which is relatively less than $\mathrm{SaOs}-2$ and which has prompted some authors (Chaudhary \& Avioli 1994, Cheng et al. 1994) to draw parallels between them and hBMS cells. Whether osteoblast maturation, as represented by phenotype, alters the expression or function of TRs is currently not known.

The bone marrow microenvironment contains various interleukins which, in synergy with IL-6, stimulate osteoclast precursor proliferation, differentiation and recruitment (Manolagas \& Jilka 1995). IL-8, also present in bone marrow, regulates osteoclastogenesis and promotes pseudopodial motility and cytoplasmic spreading (Fuller et al. 1995). Thus, a role for hBMS cells in bone remodelling is now well appreciated and our data would suggest that they may be the site of $\mathrm{T} 3$ action.

Despite the powerful role of TNF- $\alpha$ (Johnson et al. 1989) in bone resorption, we failed to demonstrate any basal or stimulated production of TNF- $\alpha$ in either cell line. Other authors have found a lack of response of TNF- $\alpha$ to IL-1 $\beta$, PTH and $1,25(\mathrm{OH})_{2} \mathrm{D}_{3}$ (Gowen et al. 1990) suggesting that it is not the primary cytokine by which osteotrophic hormones mediate bone resorption. Similarly, IL-3, GM-CSF and IL-4, which are known to be produced by osteoblasts (Lorenzo et al. 1987, Felix et al. 1988, Watanabe et al. 1990) and play a part in bone turnover, do not appear to be regulated by T3.

Since cellular heterogeneity is an inherent problem in bone marrow cell cultures, there remains a possibility that the T3-responsive cells were non-osteoblastic. We think this unlikely in our cultures since the majority of the hBMS cells were ALP positive and we did not observe chondrocytes or adipocytes in our culture system. Monoclonal antibodies such as STRO-1, which identifies early stromal cell osteoprogenitors (Simmons \& TorokStorb 1991), are potentially useful in isolating purer preparations of stromal cells but also recognise erythroid progenitors, and little is known about the antigenic epitope they recognise.

In conclusion, we have examined the effects of $\mathrm{T} 3$ on cytokine production from $\mathrm{hOb}$ and osteoblast-like cells. 
We have shown that $\mathrm{T} 3$ regulates both the production and mRNA expression of IL-6 and IL-8 in hBMS and MG63 cells but not in hOb or SaOs-2 cells. Future studies will need to examine whether these cytokines mediate T3induced bone resorption.

\section{Acknowledgements}

We would like to thank Mr G Scott and Dr S Kelsey for providing trabecular bone specimens and bone marrow aspirates, and Dr F J Hughes, Department of Periodontology, Royal London Hospital and Dr J Triffitt and R Oreffo, Nuffield Orthopaedic Hospital for their invaluable advice on the culture of primary hOb and hBMS cells. This work was supported by The Clinical Endocrinology Trust Clinical Research Fellowship (A Siddiqi) and the Royal London Hospital Special Trustees.

\section{References}

Allain TJ, Chambers TJ, Flanagan AM \& McGregor AM 1992 Tri-iodothyronine stimulates rat osteoclastic bone resorption by an indirect effect. Journal of Endocrinology 133 327-331.

Allain TJ, Yen PM, Flanagan AM \& McGregor AM 1996 The isoform-specific expression of the tri-iodothyronine receptor in osteoblasts and osteoclasts. European Journal of Clinical Investigation $\mathbf{2 6}$ 418-425.

Birch MA, Gantry AF, Walt CA, Fraser WD, Gallagher JA \& Bilbe G 1993 PCR detection in normal human and Pagetic osteoblast-like cells. Journal of Bone and Mineral Research 8 1155-1161.

Black K, Garrett IR \& Mundy GR 1991 Chinese hamster ovarian cells transfected with the murine interleukin-6 gene cause hypercalcaemia as well as cachexia, leucocytosis and thrombocytosis in tumour-bearing nude mice. Endocrinology 128 2657-2659.

Britto JM, Fenton AJ, Holloway WR \& Nicholson GC 1994 Osteoblasts mediate thyroid hormone stimulation of osteoclastic bone resorption. Endocrinology 134 169-176.

Chaudhary LR \& Avioli LV 1994 Dexamethasone regulates IL-1 $\beta$ and TNF- $\alpha$-induced IL- 8 production in human bone marrow stromal and osteoblast-like cells. Calcified Tissue International $\mathbf{5 5}$ $16-20$.

Chaudhary LR \& Avioli LV 1996 Regulation of IL-8 gene expression by IL-1 $\beta$, osteotropic hormones and protein kinase inhibitors in normal human bone marrow stromal cells. Journal of Biological Chemistry 271 16591-16596.

Chaudhary LR, Spelsberg TC \& Riggs BL 1992 Production of various cytokines by normal human osteoblast-like cells in response to IL- $1 \beta$ and TNF- $\alpha$ : lack of regulation by $17 \beta$-estradiol. Endocrinology $1302528-2534$.

Cheng S, Yang J, Rifas L, Zhang S \& Avioli LV 1994 Differentiation of human bone marrow osteogenic stromal cells in vitro: induction of the osteoblast phenotype by dexamethasone. Endocrinology 134 $277-286$.

Collin-Osdoby P, Kirch D, Anderson F, Joost O, Dean A \& Osdoby P 1996 The chemokine IL-8 as an autocrine inhibitor of osteoclast bone resorptive activity via IL- 8 receptors expressed by avian osteoclasts and human osteoclast-like cells. Journal of Bone and Mineral Research 11 S357 (abstract).

Felix R, Elford PR, Stoeckle C, Cecchini M, Wetterwald A, Trechsel U, Fleisch H \& Stadler BM 1988 Production of haemopoietic growth factors by bone tissue and bone cells in culture. Journal of Bone and Mineral Research 3 27-36.
Fuller K, Owens JM \& Chambers TJ 1995 Macrophage inflammatory protein $1-\alpha$ and IL- 8 stimulate the motility but suppress the resorption of isolated rat osteoclasts. Journal of Immunology 154 $6065-6072$

Garnero P, Vassy V, Bertholin A, Riou JP, Delmas PD 1994 Markers of bone turnover in hyperthyroidism and the effects of treatment. Journal of Clinical Endocrinology and Metabolism $\mathbf{7 8}$ 955-959.

Gowen M, MacDonald BR \& Russell GG 1990 Production of tumour necrosis factor by human osteoblasts is modulated by other cytokines, but not by osteotropic hormones. Endocrinology 126 $1250-1255$.

Haynesworth SE, Goshima J, Goldberg VM \& Caplan AI 1992 Characterisation of cells with osteogenic potential from human marrow. Bone 13 81-88.

Ishimi T, Miyaura C, He Jin C, Akatsu T, Abe E, Nakamura Y, Yamaguchi A, Yoshiki S, Matsuda T, Hirano T, Kishimoto T \& Suda T 1990 IL-6 is produced by osteoblasts and induces bone resorption. Journal of Immunology 145 3297-3303.

Johnson RA, Boyce BF, Mundy GR, Roodman GD 1989 Tumours producing human TNF induce hypercalcaemia and osteoclastic bone resorption in nude mice. Endocrinology 124 1424-1427.

Kasono K, Sato K, Han DC, Fujii Y, Tsushima T \& Shizume K 1988 Stimulation of alkaline phosphatase activity by thyroid hormone in mouse osteoblast-like cells (MC3T3): a possible mechanism of hyperalkaline phosphatasia in hyperthyroidism. Journal of Bone and Mineral Research 4 355-363.

Kim GS, Kim CH, Choi CS, Park JY \& Lee K 1997 Involvement of different second messengers in parathyroid hormone- and IL-1induced IL-6 and IL-11 production in human bone marrow stromal cells. Journal of Bone and Mineral Research 6 896-902.

Klaushofer K, Hoffman O, Gleispach H, Leis HJ, Czerwenka E, Koller K \& Peterlik M 1989 Bone resorbing activity of thyroid hormones is related to prostaglandin production in cultured neonatal mouse calvariae. Journal of Bone and Mineral Research 4 305-312.

Lakatos P \& Stern PH 1992 Evidence for direct non-genomic effects of tri-iodothyronine in rats: stimulation of the inositol phosphate second messenger system. Calcified Tissue International 50 603-608.

Lakatos P, Foldes J, Horvath C, Kiss L, Tatrai A, Takacs I, Tarjan G \& Stern P 1997 Serum IL-6 and bone metabolism in patients with thyroid function disorders. Journal of Clinical Endocrinology and Metabolism 82 78-81.

Littlewood AJ, Russell J, Harvey GR, Hughes DE, Russell RG \& Gowen M 1991a The modulation of the expression of IL-6 and its receptor in human osteoblasts in vitro. Endocrinology 129 1513-1520.

Littlewood AJ, Aarden LA, Evans DB, Russell RG \& Gowen M $1991 b$ Human osteoblast-like cells do not respond to IL-6. Journal of Bone and Mineral Research 6 141-148.

Lorenzo JA, Sousa SL, Fonseca JM, Hock JM \& Medlock ES 1987 Colony-stimulating factors regulate the development of multinucleated osteoclasts from recently replicated cells in vitro. Journal of Clinical Investigation 80 160-164.

Manolagas SC \& Jilka RL 1995 Bone marrow, cytokines and bone remodelling. New England Journal of Medicine 332 305-311.

Mosekilde L \& Melsen F 1978 A tetracycline based histomorphometric evaluation of bone resorption and bone turnover in hyperthyroidism and hyperparathyroidism. Acta Medica Scandinavica 204 97-102.

Mundy GR, Shapiro JL, Bandelin JG, Canalis EM, Raisz LG 1976 Direct stimulation of bone resorption by thyroid hormones. Journal of Clinical Investigation 58 529-543.

Nakayama H, Yokoi H \& Fugita J 1992 Quantification of mRNA by non-radioactive RT-PCR and CCD imaging system. Nucleic Acids Research 204939.

Noonan KE, Beck C, Holzmayer TA, Chin JE, Wunder JS, Andrulis IL, Gazdar AF, William CL, Griffith B \& Von Hoff DD 1990 
Quantitative analysis of multidrug resistance gene expression in human tumours by PCR. Proceedings of the National Academy of Sciences of the USA 87 7160-7164.

Passeri M, Girasole G, Giuliani N, Pedrazzoni M, Roti E, Salvi M, Minelli R, Gatti C \& Campanini C 1994 Serum soluble interleukin-6 receptors and interleukin-6 are increased in Graves' disease and correlated with thyroid hormone levels. Journal of Bone and Mineral Research 10 S143 (abstract).

Rickard DJ, Kassem M, Hefferan TE, Sarkar G, Spelsberg TC \& Riggs BL 1996 Isolation and characterisation of osteoblast precursor cells from human bone marrow. Journal of Bone and Mineral Research 11 312-324.

Robey PG \& Termine JD 1985 Human bone cells in vitro. Calcified Tissue International 37 453-460.

Roodman GD 1992 Perspectives: interleukin 6: an osteotropic factor? Journal of Bone and Mineral Research 7 475-478.

Salomon RN, Underwood R, Doyle MV, Wang A \& Libby P 1992 Increased apolipoprotein $\mathrm{E}$ and $\mathrm{c}-\mathrm{fm}$ gene expression without elevated IL-1 or IL-6 mRNA levels indicates selective activation of macrophage functions in advanced human atheroma. Proceedings of the National Academy of Sciences of the USA 89 2814-2818.

Salvi M, Girasole G, Pedrazzoni M, Passeri M, Giuliani N, Minelli R, Braverman L \& Roti E 1996 Increased serum concentrations of IL-6 and soluble IL-6 receptor in patients with Graves' disease. Journal of Clinical Endocrinology and Metabolism 81 2976-2979.

Sato K, Han DC, Fujii Y, Tsushima T \& Shizume K 1987 Thyroid hormone stimulates alkaline phosphatase activity in cultured rat osteoblastic cells (ROS 17/28) through 3,5,3'-tri-iodo-L-thyronine nuclear receptors. Endocrinology 120 1873-1881.
Siddiqi A, Burrin JM, Noonan K, James I, Wood DF, Price CP \& Monson JP 1997 A longitudinal study of markers of bone turnover in Graves' disease and their value in predicting bone mineral density. Journal of Clinical Endocrinology and Metabolism $\mathbf{8 2}$ 753-759.

Simmons PJ \& Torok-Storb B 1991 Identification of stromal cell precursors in human bone marrow by a novel monoclonal antibody, STRO-1. Blood 78 55-62.

Swolin D \& Ohlsson C 1996 Growth hormone increases IL-6 produced by human osteoblast-like cells. Journal of Clinical Endocrinology and Metabolism 81 4329-4333.

Tarjan G \& Stern P 1995 Tri-iodothyronine potentiates the stimulatory effects of interleukin $-1 \beta$ on bone resorption and medium interleukin 6 content in fetal rat limb bone cultures. Journal of Bone and Mineral Research 10 1321-1326.

Watanabe K, Tanaka Y, Morimoto I, Yahata K, Zeki K, Fujihira T, Yamashita U, Eto S 1990 Interleukin-4 as a potent inhibitor of bone resorption. Biochemical and Biophysical Research Communications 172 1035-1041.

Wilson T \& Treisman R 1988 Removal of poly (A) and consequent degradation of c-fos mRNA facilitated by $3^{\prime} \mathrm{AU}$ rich sequences. Nature 336 396-399.

Wlodarski KH 1990 Properties and origin of osteoblasts. Clinical Orthopaedics and Related Research 252 276-293.

Received 29 September 1997

Revised manuscript received 23 January 1998 Accepted 16 February 1998 